\section{UPAYA LEMBAGA PEMASYARAKATAN DALAM PENANGGULANGAN PENYALAHGUNAAN NARKOTIKA OLEH NARAPIDANA DITINJAU DARI UNDANG-UNDANG NOMOR 12 TAHUN 1995 TENTANG PEMASYARAKATAN ${ }^{1}$ Oleh: Joshua Gilbert Bawowo ${ }^{2}$}

Altje A. Musa ${ }^{3}$

Toar K. Palilingan ${ }^{4}$

\begin{abstract}
ABSTRAK
\end{abstract}
Tujuan dilakukannya penelitian yaitu untuk mengetahui bagaimanakah upaya Lembaga Pemasyarakatan dalam penanggulangan penyalahgunaan narkotika oleh narapidana dan bagaimanakah peran Lembaga Pemasyarakatan dalam penanggulangan peredaran narkotika dalam Lembaga Pemasyarakatan di mana dengan menggunakan metode penelitian hukum yuridis empiris disimpulkan bahwa: 1 . Berdasarkan data empiris di lapangan upaya Lembaga Pemasyarakatan dalam penanggulangan penyalahgunaan Narkotika oleh Narapidana di Lembaga Pemasyarakatan terkendala karena program rehabilitasi narapidana narkotika tidak efektif, daya tampung lapas yang sudah tidak sesuai (over capacity) dan penegakan tata tertib Peraturan Menteri Hukum dan HAM Nomor 6 Tahun 2013 yang masih kurang tegas. 2. Berdasarkan data empiris dilapangan, peran Lembaga Pemasyarakatan dalam penanggulangan peredaran Narkotika dalam Lembaga Pemasyarakatan tidak berjalan maksimal dikarenakan sistem pengelolaan Lembaga Pemasyarakatan yang buruk yakni masih di gabungkannya narapidana narkotika dan narapidana umum dalam satu sel, serta pengawasan keluar masuk barang bawaan dalam lapas yang tidak maksimal serta penegakan tata tertib dan hukum yang tidak tegas.

Kata kunci: lembaga pemasyarakatan; narapidana; narkotika;

\section{PENDAHULUAN}

\section{A. Latar Belakang}

Peredaran gelap narkotika yang dalam realitasnya semakin marak, ternyata pada kenyataan yang ada peredaran narkotika tidak hanya di luar saja. Tapi didalam lembaga pemasyarakatanpun pengendalian dan peredaran narkotika juga masih ada dan sudah menjadi rahasia umum untuk semua orang. Menurut data dari Badan Narkotika Nasional (BNN) terhitung dari tahun 2019 sampai bulan Januari 2020 terdapat 21.540 narapidana pengguna narkotika di Lembaga pemasyarakatan, ${ }^{5}$ jumlah yang sangat banyak itu menjadi fenomena buruk bagi Lembaga Pemasyarakatan dindonesia saat ini.

Dalam Undang-Undang Nomor 12 Tahun 1995 pasal 1 angka 3 yang tertulis "Lembaga Pemasyarakatan yang selanjutnya disebut LAPAS adalah tempat untuk melaksanakan pembinaan Narapidana dan Anak Didik Pemasyarakatan". ${ }^{6}$ Tentunya di dalam perjalanan sehari-hari dalam perjalanan keberadaan Lembaga Pemasyarakatan, sudah pasti memiliki aturan tentang tata cara pelaksanaan pembinaan Narapidana dan Anak Didik Pemasyarakatan tersebut.

\section{B. Perumusan Masalah}

1. Bagaimanakah upaya Lembaga Pemasyarakatan dalam penanggulangan penyalahgunaan narkotika oleh narapidana?

2. Bagaimanakah peran Lembaga Pemasyarakatan dalam penanggulangan peredaran narkotika dalam Lembaga Pemasyarakatan?

\section{Metode Penelitian}

Metode penelitian yang digunakan dalam penulisan skripsi ini adalah metode pendekatan yuridis empiris.

\footnotetext{
${ }^{1}$ Artikel Skripsi.

2 Mahasiswa pada Fakultas Hukum Unsrat, NIM. 16071101315

${ }^{3}$ Fakultas Hukum Unsrat, Magister IImu Hukum

${ }^{4}$ Fakultas Hukum Unsrat, Magister Ilmu Hukum
}
5 Di Akses Dari, https://bnn.go.id/resolusi- pemasyarakatan-kemenkumham-tahun-2020-21-540- narapidana/, Pada Tanggal 3 Mei 2020, Pukul 22.11 Wita. ${ }^{6}$ Pasal 1 Angka 1 Undang-Undang Nomor 12 Tahun 1995 Tentang Pemasyarakatan.




\section{PEMBAHASAN}

\section{A. Upaya Lembaga Pemasyarakatan Dalam Penanggulangan Penyalahgunaan Narkotika Oleh Narapidana.}

Bertolak dalam Pasal 1 angka 2 UndangUndang No. 12 Tahun 1995, tentang Pemasyarakatan, dinyatakan: "sistem Pemasyarakatan adalah suatu tatanan mengenai arah dan batas serta cara pembinaan Warga Binaan Pemasyarakatan berdasarkan Pancasila yang dilaksanakan secara terpadu antara pembina, yang dibina, dan masyarakat untuk meningkatkan kualitas Warga Binaan Pemasyarakatan agar menyadari kesalahan, memperbaiki diri, dan tidak mengulangi tindak pidana sehingga dapat diterima kembali oleh lingkungan masyarakat, dapat aktif berperan dalam pembangunan, dan dapat hidup secara wajar sebagai warga yang baik dan bertanggung jawab". $^{7}$

Penyalahgunaan narkotika dan psikotropika merupakan persoalan yang cukup kompleks mulai dari proses hukum hingga proses pemulihan korbannya. Persoalan hukum karena terkait dengan Undang-Undang Nomor 5 Tahun 1997 tentang Psikotropika dan Undang-Undang Nomor 35 Tahun 2009 tentang Narkotika. Di satu sisi pelanggaran terhadap kedua undangundang tersebut merupakan tindak pidana dan disisi lain korban ketergantungan terhadap narkotika wajib menjalani pengobatan dan perawatan (rehabilitasi). Berdasarkan UndangUndang Nomor 35 Tahun 2009 tentang Narkotika pasal 54, 55 dan 56 serta Surat Edaran Mahkamah Agung Nomor 07 Tahun 2009 tentang menempatkan pemakai narkoba ke dalam panti terapi dan rehabilitasi, yang mewajibkan bagi korban penyalahgunaan narkoba untuk mengikuti terapi dan rehabilitasi dan tidak boleh dipenjara, untuk itu dibutuhkan tempat terapi dan rehabilitasi yang secara professional dapat dipertanggungjawabkan.

Salah satu upaya Lembaga Pemasyarakatan dalam penanggulangan penyalahgunaan Narkotika oleh Narapidana dapat juga dilakukan dengan menjalankan kebijakan rehabilitasi sebagaimana yang diatur dalam Pasal 54 Undang-Undang Nomor 35 Tahun 2009 tentang Narkotika bahwa pecandu Narkotika dan korban penyalahgunaan

\footnotetext{
${ }^{7}$ Pasal 1 angka 2 Undang-Undang Nomor 12 Tahun 1995, tentang Pemasyarakatan,
}

Narkotika wajib menjalani rehabilitasi medis dan rehabilitasi sosial. ${ }^{8}$

Seperti halnya yang dilakukan Lapas Kelas II A Manado dimana 50 Warga Binaan diikutsertakan pada program rehabilitasi sosial narkoba, menurut Kalapas Program Rehabilitasi tersebut bertujuan agar para warga binaan benar - benar siap dan tidak akan mengulangi perbuatannya dan kegiatan ini merupakan wujud implementasi dari revitalisasi keamanan untuk para narapidana. ${ }^{9}$

Berdasarkan Undang-Undang Nomor 12 Tahun 1995 tentang Pemasyarakatan juga terlihat dengan adanya lapas narkotika yang disediakan khusus bagi pelanggar hukum kejahatan narkotika. Namun Lapas Narkotika dan Panti Rehabilitasi Narkotika belum menyeluruh tersedia di seluruh wilayah Indonesia. Tentunya Lapas umum menjadi harapan sementara dari permasalahan penanggulangan penyalahgunaan narkotika. Tetapi, Menurut Dirjen PAS Sri Puguh Budi Utami dalam pemaparan hasil pengawasan terhadap Pelayanan Publik Lapas/Rutan di Kantor Ombusdman, Senin (24/9/2020) bahwa Direktorat Jendral Pemasyarakatan (Ditjen PAS) menyiapkan pembentukan Lembaga Pemasyarakatan (Lapas) Khusus Narkotika atau LPKN di setiap wilayah Indonesia pada Tahun $2020 .^{10}$

Permasalahan meningkatnya jumlah pelaku tindak pidana narkoba memberikan implikasi terhadap peningkatan jumlah narapidana tahanan, baik secara keseluruhan maupun kasus narkoba. Situasi ini secara langsung mempengaruhi tingginya tingkat hunian di Lembaga Pemasyarakatan/ Rumah Tahanan Negara yang mengakibatkan kondisi kelebihan tingkat hunian (over capacity).

Pada Tahun 2019 Berdasarkan data Sistem Database Pemasyarakatan tanggal 14 Agustus 2019, jumlah WP seluruh Indonesia berjumlah

\footnotetext{
${ }^{8}$ Pasal 54 Undang-Undang Nomor 35 Tahun 2009 tentang Narkotika

9 Di Akses Dari, https://suluttimes.com/2020/02/lapasmanado-rehabilitasi-50-warga-binaan/ Pada Tanggal 18 Juni 2020, Pkl 10.11 WITA.

10

$\mathrm{Di}$

Akses

Dari,
}

https://www.liputan6.com/news/read/4148332/ditjenpas-siapkan-lapas-khusus-narkotika-di-seluruh-indonesiapada-2020, Pada Tanggal 19 Juni 2020, PkI 18.07 WITA. 
$265.151^{11}$ orang dengan rincian narapidana sebanyak 199.263 orang yang diikuti dengan peningkatan jumlah warga binaan pemasyarakatan kasus narkotika, hingga bulan bulan Desember 201942.649 orang prosentase jumlah warga binaan pemasyarakatan narkotika berbanding dengan warga binaan pemasyarakatan umum lainnya adalah berkisar 34 persen. ${ }^{12}$

Hal ini berakibat proporsi tahanan dan narapidana bukan saja penuh tetapi meningkat tajam, sehingga semua Rumah Tahanan Negara dan Lembaga Pemasyarakatan yang ada penuh dengan tahanan dan narapidana narkoba. Dengan meningkatnya jumlah Warga Binaan Pemasyarakatan terutama narapidana narkoba bukan tidak mungkin penyalahgunaan narkotika akan terjadi di dalam Lembaga Pemasyarakatan. Hal ini dikarenakan karena penempatan blok atau kamar antara pengguna, pengedar dan bandar menjadi satu.

Sejalan dengan pandangan tersebut kepala Badan Narkotika Nasional Provinsi Jawa Barat Brigjen Pol. Iskandar Ibrahim dalam pelatihan kegiatan Peningkatan Kemampuan Petugas Lapas melalui Modalitas Therapeutic Community (TC) di Bandung, Kamis 10/9/2019 di Hotel Ardan, Bandung, mengatakan bahwa salah satu faktor yang membuat penyalahgunaan narkotika di lapas adalah Over Capacity Lapas yang secara tidak langsung juga kegiatan rehabilitasi tidak berjalan maksimal. ${ }^{13}$

Upaya Lembaga Pemasyarakatan dalam menangani permasalahan Over Capacity ini seharusnya berfokus pada proses sebelum masuknya "orang-orang bermasalah" tersebut ke lembaga pemasyarakatan yaitu pada tahap penyidikan di kepolisian, penuntutan di kejaksaan, sampai ke tahap putusan pengadilan. Hal ini sangat penting agar tidak semua pelaku kejahatan harus masuk ke lembaga pemasyarakatan padahal beberapa tindak pidana justru dapat diselesaikan di

11 Di Akses Dari, https://tirto.id/menkumham-beri130383-narapidana-remisi-kemerdekaan-indonesia-egsP, Pada Tanggal 19 Juni 2020, Pkl 18.40 WITA.

12 Di Akses https://www.merdeka.com/peristiwa/33371kasus-narkoba-diungkap-sepanjang-2019-42649-pelakudiamankan.html, Pada Tanggal 19 Juni, Pkl 18.55 WITA.

${ }^{13} \mathrm{Di}$ Akses Dari, https://cegahnarkoba.bnn.go.id/beritaterbaru/38-persen-penghuni-lapas-kasus-narkotikasebabkan-over-capacity/, Pada tanggal 19 Juni 2020, Pkl 19.02 WITA. tingkat kepolisian dan kejaksaan tanpa harus dilakukan hukuman badan berupa pemidanaan.

kebijakan yang mungkin lebih tepat dilakukan untuk menanggulangi kelebihan daya tampung di lembaga pemasyarakatan ini salah satunya dapat ditempuh dengan pendekatan Restorative Justice, yaitu pergeseran pemidanaan dalam sistem peradilan pidana yang lebih mengutamakan keadilan bagi korban dan pelaku tindak pidana selain bisa juga dengan alternatif hukuman seperti kerja sosial dan lainnya. Bagir Manan, menguraikan substansi restorative justice yang berisi prinsip-prinsip: membangun partisipasi bersama antara pelaku, korban, dan kelompok masyarakat menyelesaikan suatu peristiwa atau tindak pidana; menempatkan pelaku, korban, dan masyarakat sebagai 'stakeholders' yang bekerja bersama dan langsung berusaha menemukan penyelesaian yang dipandang adil bagi semua pihak (win-win solutions).

Munculnya

wacana restorative justice merupakan jawaban atas hancurnya sistem pemidanaan yang ada saat ini dimana sistem tersebut sudah tidak efektif dalam menekan tingginya angka kriminalitas yang berujung pada over kapasitas di Lembaga Pemasyarakatan. Konsep peradilan pidana konvensional yang hanya berfokus pada pemidanaan dan penghukuman pelaku kejahatan belum menyentuh kepentingan korban dan/atau masyarakat yang dirugikan akibat tindak pidana yang dilakukan oleh pelaku kejahatan.

Restorative Justice lebih memandang pemidanaan dari sudut yang berbeda, yaitu berkaitan mengenai pemenuhan atas kerugian yang diderita oleh korban sehingga kedamaian menjadi tujuan akhir dari konsep ini. Konsep ini tidak serta merta menghilangkan pidana penjara, namun dalam kasus-kasus tertentu yang menimbulkan kerugian secara massal dan berkaitan dengan nyawa seseorang, maka pidana penjara masih dapat digunakan. ${ }^{14}$ Konsep Restorative Justice memiliki metode implementasi dalam bentuk mediasi penal dan diversi, meskipun keduanya memiliki cara dan

\footnotetext{
14 Henny Saida Flora, "Keadilan Restoratif Sebagai Alternatif Dalam Penyelesaian Tindak Pidana Dan Pengaruhnya Dalam Sistem Peradilan Pidana Di Indonesia", Jurnal UBELAJ, Volume 3 Nomor 4, Oktober 2018, HIm. 45.
} 
sudut pandang yang sama, namun terkadang penggunaannya berada dalam wilayah hukum yang berbeda. Mediasi penal lebih dikaitkan dengan perkara-perkara pidana biasa sedangkan diversi merupakan peristilahan dalam Sistem Peradilan Pidana Anak. Pendekatan restorative justice ${ }^{15}$ sebagai upaya mengurangi over kapasitas lembaga pemasyarakatan dilaksanakan oleh aparat penegak hukum, dengan menyelenggarakan dan menjadi penengah proses mediasi atau perdamaian antara pelaku tindak pidana dengan korban dan keluarganya. ${ }^{16}$

Penyalahgunaan narkotika juga sudah terindikasi masuk di dalam Lembaga Pemasyarakatan, ditemukannya beberapa kasus penyalahgunaan dan peredaran gelap narkoba di dalam Lembaga Pemasyarakatan dan Rumah Tahanan Negara di Indonesia. Data dari Badan Narkotika Nasional dalam Press Release Akhir Tahun 2019 terjadi pengungkapan 84 jaringan yang dilakukan BNN, tercatat sedikitnya ada 19 jaringan yang melibatkan warga binaan /narapidana terutama yang berperan sebagai pengendali jaringan di 14 Lapas. ${ }^{17}$

Dari data diatas dapat dilihat bahwa penyalahgunaan narkoba telah masuk kedalam Lembaga Pemasyarakatan yang seharusnya menjadi tempat pembinaan bagi narapidana. Lembaga Pemasyarakatan semestinya mampu menjadi tempat yang aman, tempat pembinaan warga binaan pemasyarakatan agar mereka menyadari kesalahan, memperbaiki diri dan tidak mengulangi kesalahan yang telah dilakukan. Dengan banyaknya kasus yang mencuat belakangan ini, disinyalir Lembaga pemasyarakatan dan Rutan tidak lagi steril dari narkoba.

Upaya Lembaga Pemasyarakatan dalam penanggulangan penyalahgunaan narkotika oleh Narapidana dapat dilakukan dengan menjalankan instrumen hukum Peraturan

\footnotetext{
15 Soerodibroto Soenarto.R, 2012, "KUHP Dan KUHAP dilengkapi yurisprudensi Mahkamah Agung dan Hoge Raad", Jakarta: Rajawali Pers

${ }_{16} \quad \mathrm{Di} \quad$ Akses Dari,

https://sulsel.kemenkumham.go.id/pusat-

informasi/artikel/4443-restorativejustice-solusi-over-

kapasitas-lapas-rutan, Pada Tanggal 20 Juni 2020, Pkl 13.30

${ }^{17}$ Badan Narkotika Nasional, “Press Release..."Op.Cit, HIm. 7.
}

Menteri Hukum dan HAM Nomor 6 Tahun 2013 tentang Tata Tertib Lembaga Pemasyarakatan dan Rumah Tahanan Negara secara tegas, sebab dalam dalam Pasal 4 huruf g mengatur bahwa Narapidana dilarang menyimpan, membuat, membawa, mengedarkan, dan/atau mengkonsumsi narkotika dan/atau prekursor narkotika serta obat-obatan lain yang berbahaya dan pada Pasal 10 ayat (3) mengkategorikan larangan dalam Pasal 4 huruf $\mathrm{g}$ tersebut dapat diancam dengan hukuman disiplin tingkat berat.

Contoh Pelaksanaan Peraturan Menteri tersebut dilaksanakan oleh Lembaga Pemasyarakatan Klas IIA Pontianak, dalam Berdasarkan buku Register $F$ Lembaga Pemasyarakatan Klas IIA Pontianak pada tahun 2015 proses pemasyarakatan sebagai metode pembinaan narapidana bagi narapidana yang melanggar keamanan dan ketertiban di Lembaga Pemasyarakatan Klas IIA Pontianak mengacu kepada Pasal 47 Undang-Undang Nomor 12 Tahun 1995 dimana sejumlah narapidana yang melanggar keamanan dan ketertiban pada tahun 2015 dalam hal penyalahgunaan Narkoba. Oleh karena itu Kalapas dalam mengambil tindakan penjatuhan hukuman disiplin selain menerapkan hukuman tutupan sunyi diambil tindakan tambahan yaitu menjatuhkan hukuman menunda dan/atau meniadakan hak-hak tertentu untuk jangka waktu tertentu sesuai dengan peraturan yang berlaku, seperti hak mendapatkan remisi, hak mendapatkan cuti bebas bersyarat dan hak mendapatkan cuti bersyarat. ${ }^{18}$

Dalam hal pelanggaran keamanan dan ketertiban penyalahgunaan Narkoba yang dilakukan narapidana di Lembaga Pemasyarakatan Klas IIA Pontianak tergolong ke dalam tindakan pidana, maka Kalapas menyerahkan proses pemeriksaan tindak pidana Lapas bekerja sama dengan kepolisian untuk proses penyidikan lebih lanjut. ${ }^{19}$

\footnotetext{
18 Polycarpus Bagus Widiharso Santoso, "Pelaksanaan Hukuman Disiplin Terhadap Narapidana Yang Melanggar Tata Tertib Berdasarkan Peraturan Menteri Hukum Dan Hak Asasi Manusia No. 6 Tahun 2013 Tentang Tata Tertib Lembaga Pemasyarakatan Dan Rumah Tahanan Negara Dalam Kaitannya dengan Pembinaan Narapidana (Studi Di Lembaga Pemasyarakatan Kelas II A Pontianak)", Jurnal Hukum, HIm. 10.

${ }_{19}$ Ibid, HIm. 13.
} 
Dapat dilihat tindakan Lembaga Pemasyarakatan Klas IIA Pontianak terhadap narapidana yang menyalahgunakan Narkotika tidak hanya sebatas menerapakan hukuman dalam tata tertib sesuai Permen tetapi juga menyerahkan kepada pihak penyidik untuk di proses secara lebih lanjut. Ini merupakan sikap tegas aparat dalam penegakan hukum di dalam Lapas sehingga dapat meminimalisir pelanggaran tata tertib dalam hal ini penyalahgunaan Narkotika.

Penyalahgunaan Narkotika di Lembaga pemasyarakatan terutama Lembaga pemasyarakatan narkotika bisa terjadi kapan saja narapidana dengan kasus narkotika. Banyak faktor yang menyebabkan narapidana masih melakukan penyalahgunaan narkotika di dalam Lembaga Pemasyarakatan antara lain karena barang tersebut (narkotika) masih bisa didapat di Lembaga Pemasyarakatan atau masih ada permintaan dari dalam Lembaga Pemasyarakatan. Hal lain adalah untuk menghilangkan stres selama di dalam Lembaga Pemasyarakatan atau karena adiksi/ ketergantungan.

\section{B. Peran Lembaga Pemasyarakatan Dalam Penanggulangan Peredaran Narkotika Dalam Lembaga Pemasyarakatan.}

Peredaran narkotika di Lembaga Pemasyarakatan (Lapas) sudah sangat marak. Sesuai dengan data Badan Narkotika Nasional (BNN) setiap tahun terdapat pengungkapan peredaran narkotika dari balik Lapas. Misalnya, pada tahun 2012, tujuh napi Nusakambangan terbukti menjadi otak peredaran narkotika 3,9 kilogram di Depok.

Pada tahun 2013, seorang terpidana berinisial FI alias JF yang mendekam di Lembaga Pemasayarakatan Kembang Kuning, Nusakambangan, juga terbukti menyuruh seorang kurir berinisial BL untuk mendistribusikan sabu-sabu dan heroin di DKI Jakarta.

Pada tahun 2014, terungkap dua terpidana dari Lapas Pontianak bernama Jacky Chandra dan Koei Yiong alias Memey terbukti menyuruh kurir bernama Nuraini untuk menyelundupkan $5 \mathrm{~kg}$ sabu-sabu dari Malaysia ke Indonesia. Pada tahun 2015, terpidana mati kasus narkotika, Freddy Budiman, diduga mengendalikan peredaran narkotika dari dalam Lapas Nusakambangan. ${ }^{20}$

Hal ini menunjukkan bahwa penyalahgunaan narkotika di Indonesia sudah sampai pada tingkat yang sangat mengkhawatirkan khususnya yang terjadi di Lapas, kondisi tersebut diperkuat dengan adanya pernyataan dari Presiden Republik Indonesia yang menyatakan bahwa hampir 50\% peredaran narkotika di Indonesia terjadi dan dikendalikan dari dalam Lembaga Pemasyarakatan (Lapas) dan Rumah Tahanan Negara (Rutan) dan jumlah tahanan dan narapida kasus narkotika per April 2016 mencapai 80.360.4 Peredaran narkotika di Lapas merupakan peredaran gelap yang dilakukan secara tanpa hak atau melawan hukum. ${ }^{21}$

Hal tersebut menunjukan peredaran narkotika di Lapas merupakan kejahatan luar biasa dengan sistem jaringan yang rumit, sebagai contoh, transaksi yang dilakukan jaringan narkotika Freddy dilakukan dengan berbagai modus, seperti mingling (mencampurkan dana hasil tindak pidana dengan dana dari hasil kegiatan yang legal untuk mengaburkan sumber asal dananya), penyelundupan, hingga judi daring. Kondisi tersebut berdampak pada terbentuknya pandangan negatif masyarakat terhadap pelaksanaan penegakan hukum di lingkungan institusi Pemasyarakatan. ${ }^{22}$

Maraknya peredaran narkoba di Lapas dan Rutan disebabkan oleh berbagai faktor, antara lain pertama, menurut Kepala BNN Komjen Pol. Anang Iskandar, para pengedar menganggap penjara merupakan tempat bisnis narkoba yang menggiurkan sebab para penggunanya sudah jelas. Humas BNN AKBP Slamet Pribadi mengatakan, penjara menjadi tempat perekrutan bagi pengedar baru narkoba. Salah satu modusnya, pengedar lama menjerat para pengguna narkoba di tahanan dengan memberikan bantuan uang kepada pengguna. Setelah bebas, pengguna tersebut menjadi kaki

20 Di Akses Dari, https://tirto.id/kendali-narkoba-daribalik-penjara-bC9Y, Pada Tanggal 20 Juni 2020, PkI 18.09 WITA

${ }^{21}$ Di Akses Dari, https://icjr.or.id/pengguna-dan-pecandudi-penjara-perburuk-kondisi-lapas/, Pada Tanggal 20 Juni 2020, PkI 18.30 WITA

22

Di

Akses

Dari,

https://sains.kompas.com/read/2016/08//transaksi.jaring an.freddyr, Pada tanggal 20 Juni 2020, Pkl 20.12 WITA. 
tangan pengedar yang masih berada di dalam penjara karena jeratan hutang. ${ }^{23}$

Kedua, jumlah narapidana kasus narkoba dan penempatannya dalam satu sel atau blok dengan narapidana non narkoba. Menurut Sihabudin, mantan Direktur Jenderal Pemasyarakatan Hukum dan HAM, maraknya kasus narkoba dalam penjara muncul seiring dengan melonjaknya penghuni yang berlatar belakang kasus narkoba.

Denny Indrayana, pada saat menjabat sebagai Wakil Menteri Hukum dan HAM mengungkapkan bahwa, berdasarkan data Ditjenpas Kementerian Hukum dan HAM per 1 April 2013, jumlah napi dan tahanan narkotika sebanyak 46.894 orang dengan penjabaran jumlah napi narkotika adalah 32.810 orang yang terdiri dari 19.160 orang bandar/pengedar, 13.650 orang merupakan penyalah guna, dan sebanyak 14.084 orang merupakan tahanan narkotika. Sedangkan jumlah napi dan tahanan di seluruh Indonesia berjumlah 155.525 orang. Berarti, 30,15\% dari napi dan tahanan seluruh Indonesia berlatar belakang tindak pidana narkotika. Narapidana kasus narkoba dan narapidana kasus nonnarkoba banyak ditempatkan dalam satu sel atau blok sehingga mempermudah terjadinya transaksi dan memperluas jaringan peredaran narkoba di dalam Lapas. ${ }^{24}$

Ketiga, kurangnya kontrol atau pengawasan dari petugas Lapas terhadap peredaran narkoba di Lapas atau Rutan. Hal ini dapat terjadi karena sikap petugas Lapas cenderung permisif dan komersil terhadap pelangggaran yang terjadi di dalam lingkungan Lapasnya, sebagaimana diungkapkan Benny Mamoto pada saat masih menjabat sebagai Deputi Pemberantasan BNN. Keterlibatan petugas Lapas dapat terjadi pada level paling bawah hingga level Kepala Lapas. Hal tersebut lebih disebabkan oleh faktor individu masingmasing saat berhadapan dengan pelanggaran di dalam Lapas. Selain itu, jumlah petugas Lapas atau Rutan belum memadai apabila dibandingkan dengan jumlah narapidana dalam suatu Lapas atau Rutan. $^{25}$

\footnotetext{
23 Monika Suhayati, "Penegakan Hukum Peredaran Narkoba di Lapas Dan Rutan", Info Singkat Hukum, Volume 7 Nomor 8, April 2015, HIm. 2.

${ }^{24}$ Ibid. HIm 3.

${ }^{25}$ Ibid.
}

Penegakan Hukum Peredaran Narkoba di Lapas dan Rutan dapat mengacu pada Pasal 1 angka 6 UU Nomor 35 Tahun 2009 tentang Narkotika, peredaran gelap narkotika dan prekursor narkotika merupakan setiap kegiatan atau serangkaian kegiatan yang dilakukan secara tanpa hak atau melawan hukum yang ditetapkan sebagai tindak pidana narkotika dan prekursor narkotika. ${ }^{26}$ Pasal 38 UU Narkotika lebih lanjut mengatur bahwa setiap kegiatan peredaran narkotika wajib dilengkapi dengan dokumen yang sah. Karena itu, tanpa adanya dokumen yang sah, peredaran narkotika dan prekursor narkotika tersebut dianggap sebagai peredaran gelap. ${ }^{27}$

Dalam rangka menimbulkan efek jera terhadap pelaku peredaran gelap narkotika dan prekursor narkotika, UU Narkotika mengatur mengenai pemberatan sanksi pidana, baik dalam bentuk pidana minimum khusus, pidana penjara 20 (dua puluh) tahun, pidana penjara seumur hidup, maupun pidana mati. Pemberatan pidana tersebut dilakukan dengan mendasarkan pada golongan, jenis, ukuran, dan jumlah narkotika. Bagi pengedar narkotika, setidaktidaknya terdapat 6 Pasal dalam UU Narkotika yang diancam dengan hukuman mati. Dalam hal kasus peredaran gelap narkoba di Lapas dan Rutan, ketentuan pidana dalam UU Narkotika ini berlaku baik bagi narapidana maupun petugas Lapas dan Rutan yang terbukti terlibat.

Terkait dengan peredaran narkotika di Lapas konsideran menimbang Undang-Undang Nomor 12 Tahun 1995 tentang Pemasyarakatan (UU Pemasyarakatan) menyebutkan sistem pemasyarakatan yang dilaksanakan di Lapas merupakan rangkaian penegakan hukum yang bertujuan agar warga binaan pemasyarakatan menyadari kesalahannya, memperbaiki diri, dan tidak mengulangi tindak pidana sehingga dapat diterima kembali oleh lingkungan masyarakat, dapat aktif berperan dalam pembangunan, dan dapat hidup secara wajar sebagai warga yang baik dan bertanggung jawab. ${ }^{28}$

\footnotetext{
${ }^{26}$ Pasal 1 angka 6 Undang-Undang Nomor 35 Tahun 2009 tentang Narkotika

${ }^{27}$ Pasal 38 Undang-Undang Nomor 35 Tahun 2009 tentang Narkotika

${ }^{28}$ Priyatno Dwidja, 2013, "Sistem Pelaksanaan Pidana Penjara di Indonesia", Bandung: PT Refika, HIm. 57.
} 
Sebagai peraturan pelaksanaan UU Pemasyarakatan, dikeluarkan Peraturan Menteri Hukum dan Hak Asasi Manusia Nomor 6 Tahun 2013 tentang Tata Tertib Lembaga Pemasyarakatan dan Rumah Tahanan Negara (Permen No. 6 Tahun 2013). Pasal 4 angka 7 Permen tersebut melarang setiap narapidana atau tahanan menyimpan, membuat, membawa, mengedarkan, dan/atau mengkonsumsi narkotika dan/atau prekursor narkotika serta obat-obatan lain yang berbahaya. ${ }^{29}$ Pelanggaran terhadap larangan ini termasuk yang diatur dalam Pasal 10 ayat (3). Adapun dalam hal pelanggaran yang dilakukan oleh narapidana atau tahanan diduga tindak pidana, Kepala Lapas atau Kepala Rutan meneruskan kepada instansi yang berwenang (Pasal 17 Permen No. 6 Tahun 2013). ${ }^{30}$

Dalam hal penegakan hukum bagi petugas Lapas, UU Narkotika maupun UU Pemasyarakatan tidak mengatur secara khusus sanksi maupun ketentuan pidana bagi petugas Lapas atau Rutan yang terduga terlibat peredaran gelap di Lapas atau Rutan. Terhadap petugas Lapas yang terlibat peredaran gelap narkoba, dilakukan upaya pemberian hukuman disiplin sebagaimana diungkapkan mantan Dirjen Pemasyarakatan Hukum dan HAM, Sihabudin, bahwa hukuman disiplin tingkat berat telah dijatuhkan kepada petugas yang terlibat dalam peredaran narkoba di penjara. Tahun 2010, 32 petugas dikenai sanksi disiplin berat dan 27 petugas pada tahun 2011.

Selain itu juga terdapat petugas Lapas yang diproses secara pidana di pengadilan dengan menggunakan ketentuan pidana dalam UU Narkotika. Hal ini sudah diterapkan antara lain oleh majelis hakim Pengadilan Negeri Serang yang menghukum petugas Lapas Kelas II A Serang, Wisnu Ari Wibowo, enam tahun penjara dan denda Rp1 miliar pada 22 Oktober 2014. Wisnu Ari Wibowo dinyatakan terbukti secara sah dan meyakinkan menguasai narkotika jenis ekstasi sebanyak 100 butir sesuai Pasal 112 UU Narkotika. Berdasarkan fakta persidangan, petugas Lapas tersebut

${ }^{29}$ Pasal 4 Angka 7 Peraturan Menteri Hukum dan Hak Asasi Manusia Nomor 6 Tahun 2013 tentang Tata Tertib Lembaga Pemasyarakatan dan Rumah Tahanan Negara.

30 Pasal 17 Peraturan Menteri Hukum dan Hak Asasi Manusia Nomor 6 Tahun 2013 tentang Tata Tertib Lembaga Pemasyarakatan dan Rumah Tahanan Negara. adalah kurir dari Dodi Kusmiyanto, terpidana narkoba yang masih menjalani masa hukuman di penjara tersebut. ${ }^{31}$

Sedangkan Pada Tahun 2015, Plt. Direktur Jenderal Pemasyarakatan Ma'mun menerangkan terhitung sejak Januari - Mei 2015, Kemenkumham telah memberikan hukuman disiplin kepada 111 orang petugas Pemasyarakatan, 18 di antaranya karena keterkaitannya dengan narkoba. "Dari 18 petugas Pemasyarakatan yang terlibat kasus narkoba, 10 orang sudah dijatuhi sanksi hukuman tingkat berat dan delapan orang sedang dalam proses penjatuhan hukuman disiplin. ${ }^{32}$

Terkait kasus Freddy Budiman, Menteri Hukum dan Hak Asasi Manusia, Yasonna Laoly menyatakan oknum sipir yang terlibat dalam jaringan peredaran narkoba akan mendapat sanksi tegas. Lebih lanjut dikemukakan, Sipir yang melanggar aturan kepegawaian harus dipecat dan dipidana. Semua sipir Lapas telah diingatkan agar tidak membantu masuknya barang terlarang ke lingkungan Lapas. Sanksi bagi pelanggar adalah rotasi sampai dengan pemecatan dan dipidana. ${ }^{33}$

Sistem keamanan di Lembaga Pemasyarakatan pada dasarnya merupakan suatu kegiatan untuk mewujudkan kehidupan dan penghidupan yang teratur, aman dan tentram. Upaya ini dilakukan dengan terencana, terarah dan sistematis sehingga dapat menjamin terselenggaranya kegiatan perawatan tahanan dan pembinaan Warga Binaan Pemasyarakatan dalam rangka pencapaian tujuan Pemasyarakatan. Untuk menjamin tercapainya tujuan pemasyarakatan dibutuhkan situasi dan kondisi yang aman dan tertib sehingga perlu dilakukan langkah langkah penanggulangan gangguan keamanan dan ketertiban dalam hal ini yaitu penanggulangan peredaran narkotika. Upaya-upaya

${ }^{31}$ Di Akses Dari, https://kabar6.com/jadi-kurir-narkobasipir-Ip-serang-diganjar-6-tahun/, Pada Tanggal 20 Juni 2020, Pkl 20.05 WITA.

32 Di Akses Dari, https://news.detik.com/berita/d2949671/bantu-napi-dapatkan-narkoba-petugas-lapastanjungpinang-dipecat, Pada Tanggal 20 Juni 2020, Pkl 20.34 WITA.

33

Di

Akses

Dari, https://nasional.kompas.com/Menkumham/Freddy/Budi man, Pada Tanggal 20 Juni 2020, Pkl 23.09 WITA. 
penanggulangan peredaran narkotika dapat dilakukan sebagai berikut:

\section{Upaya Preventif}

Upaya preventif merupakan usaha pencegahan terhadap timbulnya masalah. Upaya preventif juga dapat di maksud sebagai suatu kegiatan yang dilakukan secara sistematis, terencana dan terarah untuk menjaga sesuatu hal agar tidak meluas atau timbul. Seperti halnya yang dilakukan oleh Lapas kelas IIA Manado, Menurut Kalapas modus peredaran narkotika di Lapas kelas IIA Manado dilakukan dengan lewat titipan makanan.

Untuk mengatasi aksi seperti tak terulang lagi, sosialisasi kepada pegawai mengajak dan ingatkan tentang integritas dan komitmen jangan sampai terjadi peredaran narkoba. Kepada pengunjung jangan sampai membawa barang yang dilarang, kepada WBP disosialisasikan aturan yang ada dan mereka tahu hal seperti ini dilarang tapi secara pribadi masih yang berbuat. Serta, menurut Kalapas saat itu Sulistyo Wibowo menilai butuh peran pemerintah untuk berkomitmen melakukan pencegahan dan pemberantasan hingga antisipasi dalam mengatasi masalah tersebut. ${ }^{34}$

Upaya yang dilakukan oleh Lembaga Pemasyarakatan dalam mencegah penyelundupan peredaran narkotika dapat dilakukan berdasarkan Standar Operasional Prosedur (SOP) yang ada, seperti Surat Edaran nomor : PAS-182.PK.01.04.02 tahun 2016 tanggal 29 April 2016 tentang Peningkatan Pencegahan Penyelundupan Barang Terlarang di Lembaga Pemasyarakatan, Rutan dan Cabang Rutan. Surat edaran tersebut digunakan sebagai pedoman dalam rangka peningkatan pencegahan penyelundupan barang terlarang. Adapun jalur-jalur penyelundupan narkotika ke dalam Lembaga Pemasyarakatan yaitu : $:^{35}$
a. Jalur pertama melalui pengunjung (besuk) keluarga dan handai taulan;
b. Jalur kedua melalui Petugas;

\footnotetext{
$34 \quad$ Di Akses Dari,

https://manado.tribunnews.com/2019/08/30/ini-caralapas-manado-antisipasi-peredaran-narkoba-di-lapas, Pada Tanggal 21 Juni 2020, Pkl 01:35 WITA.

${ }^{35}$ Surat Edaran nomor : PAS-182.PK.01.04.02 tahun 2016 tanggal 29 April 2016 tentang Peningkatan Pencegahan Penyelundupan Barang Terlarang di Lembaga Pemasyarakatan, Rutan dan Cabang Rutan.
}

c. Jalur ketiga melalui narapidana yang mengikuti program asimilasi di luar Lembaga Pemasyarakatan;

d. Jalur keempat melalui Warga Binaan Pemasyarakatan yang keluar/masuk Lembaga Pemasyarakatan/Rutan untuk keperluan proses hukum dan/atau persidangan, izin keluar Lembaga Pemasyarakatan dengan alasan penting dan Berobat ke Rumah Sakit.

e. Jalur kelima melalui bahan makanan Napi/Tahanan.

f. Jalur keenam melalui toko/warung koperasi yang beroperasi di dalam blok dengan cara memasukkan barang terlarang ke dalam bungkusan barang di jual seperti kopi/teh sachet, mie instant, detergent, rokok, air galon, dan lainnya.

g. Jalur ketujuh melalui kunjungan resmi/terjadwal terkait pembinaan narapidana (ceramah, pendidikan, angkut sampah, kerja sama dengan pihak ketiga dan lainnya).

h. Jalur kedelapan melalui kunjungan insidentil/asimilasi (seperti peringatan hari-hari besar, peresmian, dan lainnya);

i. Jalur kesembilan melalui tembok keliling dengan cara antara lain melemparkan barang dan memanfaatkan drone serta melalui binatang.

Sehingga perlu untuk dilakukan kegiatan pengeledahan baik kepada petugas dan warga binaan secara rutin dan tes narkotika kepada warga binaan dan petugas, serta perlu untuk meningkatkan sarana dan prasarana serta mutu SDM Petugas Lembaga Pemasyarakatan, peningkatan sarana dan prasarana juga diperlukan, baik dari jumlah maupun mutunya. Sarana dan prasarana yang baik akan ikut membantu kinerja petugas Lembaga Pemasyarakatan yang akan meningkatkan SDM petugas Lembaga Pemasyarakatan itu sendiri. Dalam upaya untuk meningkatkan SDM petugas Lembaga Pemasyarakatan yang bersih, jujur, bermoral tidak korup, dan dapat di percaya untuk menegakkan nilainilai kebenaran dan keadilan maka harus dilakukan peningkatan terhadap pendidikan petugas Lembaga Pemasyarakatan.

2. Upaya Represif

Tindakan represif menurut Kamus Besar Bahasa Indonesia(KBBI) Tindakan Represif 
adalah tindakan yang bersifat represif (menekan, mengekang, menahan, atau menindas) bersifat menyembuhkan. ${ }^{36}$

Pada umumnya tindakan represif yang dilakukan di Lembaga Pemasyarakatan adalah penindakan terhadap warga binaan pemasyarakatan yang sebagai narapidana penyalahguna narkotika. Penindakan represif tersebut lebih menitikberatkan tugas dan tanggungjawab kepada petugas pemasyarakatan yang ditunjuk sebagai Tim PP di dalam memberikan sanksi terhadap peredaran narkotika di dalam Lembaga Pemasyarakatan.

Jika terdapat narapidana yang melanggar aturan yang ada di Lembaga Pemasyarakatan dan terbukti bersalah maka narapidana tersebut dikenakan sanksi yang diatur dalam Pasal 9 dan Pasal 10 Permenkumham No.6 Tahun 2013. Adapun bentuk-bentuknya antara lain bisa dilakukan dengan cara melaporkan kepada pihak yang berwajib, kurungan sunyi, tidak diberikan hak remisinya, tidak diperbolehkan dikunjungi dalam waktu tertentu, dan lain-lain. ${ }^{37}$

3. Koordinasi dan kerjasama antar lembaga

Peran serta dan kontribusi semua aparat penegak hukum, khususnya Kepolisian, BNN dan Lembaga Pemasyarakatan sendiri menjadi penting. Sasarannya adalah penyalahgunaan dan pengendalian peredaran narkotika di dalam Lapas dapat dicegah dan diberantas. Kesemua elemen tersebut perlu secara bersama-sama dan berkesinambungan mencurahkan perhatian serta berpartisipasi aktif dalam rangka upaya terpadu pencegahan dan pemberantasan penyalahgunaan peredaran gelap narkotika di Lembaga Pemasyarakatan. Dengan demikian dalam upaya pencegahan dan pemberantasan peredaran narkotika, khususnya di Lapas dan Rutan, dilakukan kerjasama antara lain dengan BNN dan Polri, termasuk di daerah-daerah dengan melibatkan Polres-Polres maupun Badan Narkotika Nasional Kabupaten (BNNK). ${ }^{38}$

\footnotetext{
${ }^{36} \mathrm{KBBI}$, Arti Kata Represif.

${ }^{37}$ Pasal 9 dan Pasal 10 Peraturan Menteri Hukum dan Hak Asasi Manusia Nomor 6 Tahun 2013 tentang Tata Tertib Lembaga Pemasyarakatan dan Rumah Tahanan Negara ${ }^{38}$ Risa Andika Sari, Suhaimi, Muazzin, "Upaya Terpadu Pencegahan dan Pemberantasan Penyalahgunaan Peredaran Gelap Di Lapas Kelas IIA Banda Aceh ", Law Journal Volume 2 Nomor 1, April 18, HIm, 157.
}

Kerjasama diwujudkan dengan adanya MoU Kementerian Hukum dan Hak Asasi Manusia Republik Indonesia dengan Badan Narkotika Nasional (BNN) melalui Peraturan Bersama Menteri Hukum dan HAM RI dan Kepala Badan Narkotika Nasional RI Nomor: M.HH09.HM.03.02 Tahun 2011 Nomor: 12/PERBNN/XII/2011 tentang Pedoman Pelaksanaan Pencegahan dan Pemberantasan Penyalahgunaan dan Peredaran Gelap Narkotika (P4GN) di dalam Lembaga Pemasyarakatan dan Rumah Tahanan Negara. Dalam MoU ini secara tegas mengamanatkan kegiatan P4GN dilakukan secara integratif, koordinatif, profesionalisme dan proporsionalitas, preventif dan represif, efektif dan efesien, proaktif, transparan dan akuntabel. ${ }^{39}$

Selain itu terdapat MoU yang terjalin antara Kementerian Hukum dan HAM RI dan Kepolisian Negara RI Nomor: M.HH02.HM.05.02 Tahun 2014 Nomor: B/4/III/2014 tentang Kerjasama dalam Upaya Pencegahan dan Pemberantasan Tindak Pidana Korupsi dan Narkoba. Pencegahan dan pemberantasan penyalahgunaan dan peredaran gelap narkotika di Lapas dilakukan dengan saling mendukung (support), serta saling memberikan informasi. ${ }^{40}$

Ketentuan perjanjian yang dituangkan dalan MoU tersebut, membuat para lembaga terikat untuk sama-sama dan saling melengkapi dalam penanggulangan peredaran Narkotika di Lapas, butuh adanya komitmen untuk berjalan bersama dan membuang ego antar lembaga agar dapat sukses dalam memberantas peredaran Narkotika di Lapas.

\section{PENUTUP}

\section{A. Kesimpulan}

1. Berdasarkan data empiris di lapangan upaya Lembaga Pemasyarakatan dalam penanggulangan penyalahgunaan Narkotika oleh Narapidana di Lembaga Pemasyarakatan terkendala karena program rehabilitasi narapidana narkotika tidak efektif, daya tampung lapas yang sudah tidak sesuai (over capacity) dan penegakan tata tertib Peraturan Menteri Hukum dan HAM

\footnotetext{
${ }^{39}$ Ibid.

${ }^{40}$ Ibid. HIm 158.
} 
Nomor 6 Tahun 2013 yang masih kurang tegas.

2. Berdasarkan data empiris dilapangan, peran Lembaga Pemasyarakatan dalam penanggulangan peredaran Narkotika dalam Lembaga Pemasyarakatan tidak berjalan maksimal dikarenakan sistem pengelolaan Lembaga Pemasyarakatan yang buruk yakni masih di gabungkannya narapidana narkotika dan narapidana umum dalam satu sel, serta pengawasan keluar masuk barang bawaan dalam lapas yang tidak maksimal serta penegakan tata tertib dan hukum yang tidak tegas.

\section{B. Saran}

1. Perlu adanya Program rehabilitasi yang baik dari Lembaga, peningkatan daya tampung narapidana dan pelaksanaan restorative sistem dalam peradilan yang maksimal, serta penegakan tata tertib Peraturan Menteri Hukum dan HAM Nomor 6 Tahun 2013 yang tegas dan tidak pandang bulu.

2. Perlu adanya adanya pengelolaan sistem Lembaga Pemasyarakatan dalam hal pemisahan antara narapidana narkotika dan narapidana umum yang menyeluruh di seluruh Lembaga Pemasyarakatan, upaya penanggulangan peredaran yang sistematis dalam hal ini upaya preventif dan represif serta peningkatan kerjasama dan koordinasi antara Lembaga Pemasyarakatan dengan lembaga lainnya dalam upaya penegakan hukum terhadap peredaran narkotika.

\section{DAFTAR PUSTAKA}

Aditama Prodjodikoro Wirjono, 1989, "AsasAsas Hukum Pidana di Indonesia", Bandung: PT Eresco.

Darwin Prints, 1997, "Hukum Anak Indonesia", Medan, PT.Citra Aditya Bakti.

Gatot Supramo, 2000, "Hukum Acara Pengadilan Anak", Jakarta, Djambatan,2000.

Hari Sasangka, 2003, "Narkotika dan Psikotropika dalam Hukum Pidana", Bandung, Mandar Maju.

Moh. Taufik Makaro,2005 "Tindak Pidana Narkotika", Jakarta: Ghalia.
PAF Lamintang, 2004,"Hukum Penitersier Indonesia". Bandung, Alumni.

Praetyo Teguh,2012, "Hukum Pidana", Jakarta: Rajawali Pers

Priyatno Dwidja, 2013, "Sistem Pelaksanaan Pidana Penjara di Indonesia", Bandung: PT Refika

Suratman, H.Philips Dillah, "Metode Penelitian Hukum", Bandung:Alfabeta, HIm.32,;terkutip;Peter Mahmud Marzuki, 2008, "Penelitian Hukum", Kencana Prenada Media Group,Jakarta.

Sudarto, 1981, "Hukum dan Hukum Pidana", Cetakan Pertama. Bandung, Alumni.

Soerodibroto Soenarto.R, 2012, "KUHP Dan KUHAP dilengkapi yurisprudensi Mahkamah Agung dan Hoge Raad", Jakarta: Rajawali Pers

Sudarto, 1986, "Hukum Dan Hukum Pidana", Bandung: Alumni

Sumaryanti, 2007, "Peradilan Koneksitas Di Indonesia Suatu Tinjauan Ringkas".Jakarta.

\section{JURNAL/KARYA ILMIAH}

Hikmoro, Abi, "Peranan dan Fungsi Praperadilan Dalam Penegakan Hukum Pidana Di Indonesia", Jurnal Hukum Volume 3 Nomor 2, April 2013.

Henny Saida Flora, "Keadilan Restoratif Sebagai Alternatif Dalam Penyelesaian Tindak Pidana Dan Pengaruhnya Dalam Sistem Peradilan Pidana Di Indonesia", Jurnal UBELAJ, Volume 3 Nomor 4, Oktober 2018.

Monika Suhayati, "Penegakan Hukum Peredaran Narkoba di Lapas Dan Rutan", Info Singkat Hukum, Volume 7 Nomor 8, April 2015.

Polycarpus Bagus Widiharso Santoso, "Pelaksanaan Hukuman Disiplin Terhadap Narapidana Yang Melanggar Tata Tertib Berdasarkan Peraturan Menteri Hukum Dan Hak Asasi Manusia No. 6 Tahun 2013 Tentang Tata Tertib Lembaga Pemasyarakatan Dan Rumah Tahanan Negara Dalam Kaitannya dengan Pembinaan Narapidana (Studi Di Lembaga Pemasyarakatan Kelas "I A Pontianak)", Jurnal Hukum.

Press Release Akhir Tahun 2019 Badan Narkotika Nasional. 
Riky Novarizal, "Narapidana Narkotika Di Dalam Lembaga Pemasyarakatan Umum", journal.uir.ac.id, HIm.

\section{PERATURAN PERUNDANG-UNDANGAN}

Undang-Undang Nomor 35 Tahun 2009 Tentang Narkotika

Undang-Undang Nomor 12 Tahun 1995 Tentang Pemasyarakatan

Peraturan Menteri Hukum dan Hak Asasi Manusia Nomor 6 Tahun 2013 tentang Tata Tertib Lembaga Pemasyarakatan dan Rumah Tahanan Negara.

Surat Edaran nomor : PAS-182.PK.01.04.02 tahun 2016 tanggal 29 April 2016 tentang Peningkatan Pencegahan Penyelundupan Barang Terlarang di Lembaga Pemasyarakatan, Rutan dan Cabang Rutan

\section{INTERNET/KAMUS}

Di Akses

Dari, https://tiurmargareth.wordpress.com/huk um/hukum-publik/, Pada Tanggal 3 Mei 2020, Pukul 21.00 Wita.

Di

Akses

Dari,

http://ditjenpp.kemenkumham.go.id/kegia tan-umum/3136-narkotika-merupakansalah-satu-tindak-pidana-khusus-dalamruu-kuhp.html, Pada Tanggal 2 Mei 2020, Pukul 21.36 Wita.

Di Akses Dari, https://bnn.go.id/penggunaannarkotika-kalangan-remaja-meningkat/, Pada Tanggal 3 Mei 2020 Wita, Pukul 13.15 Wita.

Di Akses Dari, https://bnn.go.id/resolusipemasyarakatan-kemenkumham-tahun2020-21-540-narapidana/, Pada Tanggal 3 Mei 2020, Pukul 22.11 Wita.

Di Akses Dari, www.lapasnarkotikajkt.com, Pada Tanggal 12 Juni 2020, Pkl 21.57 WITA.

Di Akses Dari, https://www.hukumonline.com/klinik/det ail/ulasan/ ini-aturan-tentangpenggolongan-narkotika-di-indonesia/, Pada Tanggal 13 Juni 2020, Pkl 01.34 WITA.

Di Akses Dari, http://jurnal.ensiklopediaku.org/ojs-2.4.83/, Pada Tanggal 14 Juni, Pkl, 02.03 WITA.

Di Akses Dari, https://suluttimes.com/2020/02/lapas-

manado-rehabilitasi-50-warga-binaan/ Pada Tanggal 18 Juni 2020, Pkl 10.11 WITA.

Di

https://www.liputan6.com/news/read/414

8332/ditjen-pas-siapkan-lapas-khususnarkotika-di-seluruh-indonesia-pada-2020,

Pada Tanggal 19 Juni 2020, Pkl 18.07 WITA.

Di Akses Dari, https://tirto.id/menkumhamberi-130383-narapidana-remisi-

kemerdekaan-indonesia-egsP, Pada Tanggal 19 Juni 2020, Pkl 18.40 WITA.

Di Akses

https://www.merdeka.com/peristiwa/333

71-kasus-narkoba-diungkap-sepanjang2019-42649-pelaku-diamankan.html, Pada Tanggal 19 Juni, Pkl 18.55 WITA.

Di Akses Dari, https://cegahnarkoba.bnn.go.id/beritaterbaru/38-persen-penghuni-lapas-kasusnarkotika-sebabkan-over-capacity/, Pada tanggal 19 Juni 2020, Pkl 19.02 WITA.

Di Akses Dari, https://sulsel.kemenkumham.go.id/pusatinformasi/artikel/4443-restorativejusticesolusi-over-kapasitas-lapas-rutan, Pada Tanggal 20 Juni 2020, Pkl 13.30

Di Akses Dari, https://tirto.id/kendali-narkobadari-balik-penjara-bC9Y, Pada Tanggal 20 Juni 2020, Pkl 18.09 WITA.

Di Akses Dari, https://icjr.or.id/pengguna-danpecandu-di-penjara-perburuk-kondisilapas/, Pada Tanggal 20 Juni 2020, Pkl 18.30 WITA.

Di Akses Dari, https://sains.kompas.com/read/2016/08// transaksi.jaringan.freddyr, Pada tanggal 20 Juni 2020, Pkl 20.12 WITA. 